\title{
PREPARATION AND TESTING OF ANTIGENS FOR THE DEMONSTRATION OF MYCOPLASMA ANTIBODIES IN PIGS BY A SOLID-PHASE RADIOIMMUNOASSAY
}

\author{
J. HAMPL, J. TOMÁNEK, L. RODÁK, F. KUKSA and M. SEDLÁČEK
}

Veterinary Research Institute, 62132 Brno

Received fuly 28, 1980

\begin{abstract}
Hampl J., J. Tománek, L. Rodák, F. Kuksa and M. Sedláček: Preparation and Testing of Antigens for the Demonstration of Mycoplasma Antibodies in Pigs by a Solid-Phase Radioimmunoassay. Acta vet. Brno. 50, 1981: 67-72.

Three types of antigen, namely corpuscular, disaggregated with sodium dodecyl sulphate and disaggregated by sonication, were prepared from Mycoplasma hyopneumoniae and Mycoplasma hyorhinis strains and used for the demonstration of antibody by a solid-phase radioimmunoassay in the sera of pigs infected experimentally with these two mycoplasma strains. The best suited from the practical point of view was the antigen prepared by ultrasonic disaggregation, diluted 1:50 and incubated in polystyrene microtubes for 16 hours. The test serum and ${ }^{125}$ I-labelled antibody were incubated for 3 hours; prolongation of this period had no effect on the results. The radioactivity of the administered ${ }^{125} \mathrm{I}$-labelled antibody ranged from 10000 to 80000 counts per minute (cpm); its level had no significant effect on antibody titres demonstrated in the sera.
\end{abstract}

Mycoplasma hyopneumoniae, Mycoplasma hyorhinis, enzootic pneumonia, corpuscular antigen, disaggregated antigen, ${ }^{225} I$-labelled antibody to swine IgG.

Radioimmunoassay (RIA) is being used increasingly in the diagnosis of farm animal diseases. It is sensitive and reliable, allows an objective evaluation of the results and is economic in terms of cost where large numbers of samples are to be processed.

One of the main problems in pig herds under intensive husbandry is respiratory disease conditions. A considerable role in its development is played by mycoplasmas, particularly Mycoplasma hyorhinis and Mycoplasma hyopneumoniae, which have been isolated from the lungs of pigs with enzootic pneumonia. Their isolation presents great difficulties because it requires special media and prolonged cultivation. The demonstration of antibodies in pigs exhibiting no clinical and pathological signs of enzootic pneumonia may be an indication of their subclinical disease and allows early culling of such possible sources of infection. The present study was designed to test three differently prepared mycoplasma antigens as to their suitability for solid-phase RIA and other conditions of the assay.

Preliminary results were presented previously (Hampl et al. 1978). Recently Taylor (1979) described demonstration by solid-phase RIA of immunoglobulin class-specific antibody in mice after infection with Mycoplasma pulmonis.

\section{Materials and Methods}

Mycoplasma hyorhinis and M. hyopneumoniae strains used for the preparation of antigens were grown in a liquid medium according to Goiš et al. (1975) for 48 and $120 \mathrm{hrs,} \mathrm{respectively.} \mathrm{The}$ medium was then centrifuged at $10000 \mathrm{rpm}$ for 30 minutes and the sediment was washed three times with phosphate buffered saline (PBS), $\mathrm{pH}$ 7.2, resuspended in PBS to give a volume 100 times smaller than the original culture medium volume and used for the preparation of antigens. 
The antigens were prepared in three different ways. They were

1) suspensions of washed mycoplasma of the corresponding strains, i. e. corpuscular antigen;

2) antigens prepared by disaggregation of mycoplasma suspension with sodium dodecyl sulphate

(Bruggmann and Keller 1977);

3) antigens prepared by ultrasonic disaggregation of mycoplasma suspension for $5 \times 30 \mathrm{sec}$. at $20 \mathrm{kHz}$ using an Artec sonic dismembrator model 300 .

Standardization of suitable dilutions of the disaggregated antigens was carried out by measurement in a spectrophotometer at the wavelength of $280 \mathrm{~nm}$.

Antibodies to swine IgG were prepared according to Rodák et al. (1978) and the obtained rabbit anti-swine IgG fraction was labelled with ${ }^{125} \mathrm{I}$ by the chloramine-T method as modified by McConahey and Dixon (1966). Unreacted radioactive iodide was removed by dialysis against PBS, $\mathrm{pH} 7.2$; checks upon the completeness of removal were carried out by ascending paper chromatography according to Schmidt et al. (1974) and evaluated in an Actigraph III, Nuclear Chicago.

The RIA procedure was as follows: Polystyrene microtubes inserted into wells of a plastic carrier plate were used as the solid phase for antigen coating. Antigens diluted appropriately with carbonate buffer, $\mathrm{pH}$ 9.8, were pipetted in $0.05 \mathrm{ml}$ amounts into the microtubes. After drying, corpuscular antigen coated the inner wall of the microtube and was fixed with 4 per cent paraformaldehyde for 15 minutes. Disaggregated antigens were incubated in microtubes in a moist chamber for 16 hours at room temperature. After antigen was aspirated, the microtubes were filled to the rim with a 0.5 per cent solution of bovine serum albumin in PBS, $\mathrm{pH} 7.2$, and left undisturbed for 5 minutes. This procedure was repeated three times. After the microtubes were dried, test serum diluted $1: 160$ to $1: 327680$ was pipetted into them in $0.05 \mathrm{ml}$ amounts. Each sample was processed in triplicate. The incubation period of the serum was tested over the range of 3 to $16 \mathrm{hrs}$. After the incubation was completed, the microtubes were washed three times with PBS. Afterwards $0.05 \mathrm{ml}$ of ${ }^{125}$ I-labelled rabbit anti-swine IgG antibody having radioactivity of approximately 20000 counts per minute (cpm) was pipetted into each microtube. (The radioactivity range tested in our experiments was 10000 to $80000 \mathrm{cpm}$.) The incubation period of the labelled antibody. was tested over the range of 3 to $8 \mathrm{hrs}$. After the incubation was completed and the labelled antibody was aspirated, the microtubes were washed three times with PBS, pH 7.2, dried and counted in an NE 1600 counter (Nuclear Enterprises) or an NRG 603 gamma counter (Tesla).

Hyperimmune sera for the binding of specific antibodies to the antigens were obtained from pigs immunized with the corresponding mycoplasma species. A serum notoriously negative for mycoplasma antibody was tested for comparison. Checks were made to detect possible non-specific binding of ${ }^{125} \mathrm{I}$-labelled anti-swine $\mathrm{IgG}$ antibody to the antigens and 0.5 per cent bovine serum albumin.

A serum was regarded as positive if the ratio of its activity to the activity notoriously negative serum in the same dilution was 2.0 or greater. When the binding ratio was 1.5 do 2.0 , the sera were regarded as dubious.

Antibody titres obtained by the solid-phase RIA were compared with those obtained by the indirect haemagglutination method as modified by Lam and Switzer (1971).

\section{Results}

The binding of specific serum mycoplasma antibodies to the corresponding antigens was tested with three types of antigen, namely corpuscular, disaggregated with sodium dodecyl sulphate and disaggregated by sonication, prepared from $M$. hyopneumoniae and $M$. hyorhinis strains. The sera employed for testing were hyperimmune sera from pigs immunized with the corresponding mycoplasma strain and a notoriously negative pig serum. Fig. 1 shows the radioactivity in the individual dilutions of the hyperimmune and negative serum obtained with antigens to $M$. hyorhinis. At the dilution of 1:327 680 the level of radioactivity of the two sera was practically the same. Fig. 2 shows the ratio of radioactivity in the individual pairs of the hyperimmune and negative serum as a function of the dilution. It can be seen that at the dilution of 40960 antibody was demonstrated with all the three types of antigen, but at the dilution of 1:81920 only with the antigen prepared by ultrasonic disaggregation. The indirect haemagglu- 
Fig. 1

Radioactivity of hyperimmune and negative serum obtained with three types of antigen prepared from Mycoplasma hyorhinis

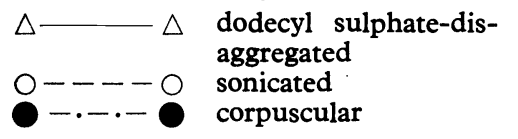

Fig. 2

Ratio of radioactivity in the individual pairs of hyperimmune and negative serum as a function of the dilution $\mathbf{P} / \mathbf{N}=$ positive/negative serum Same M. hyorhinis antigens as in Fig. 1.
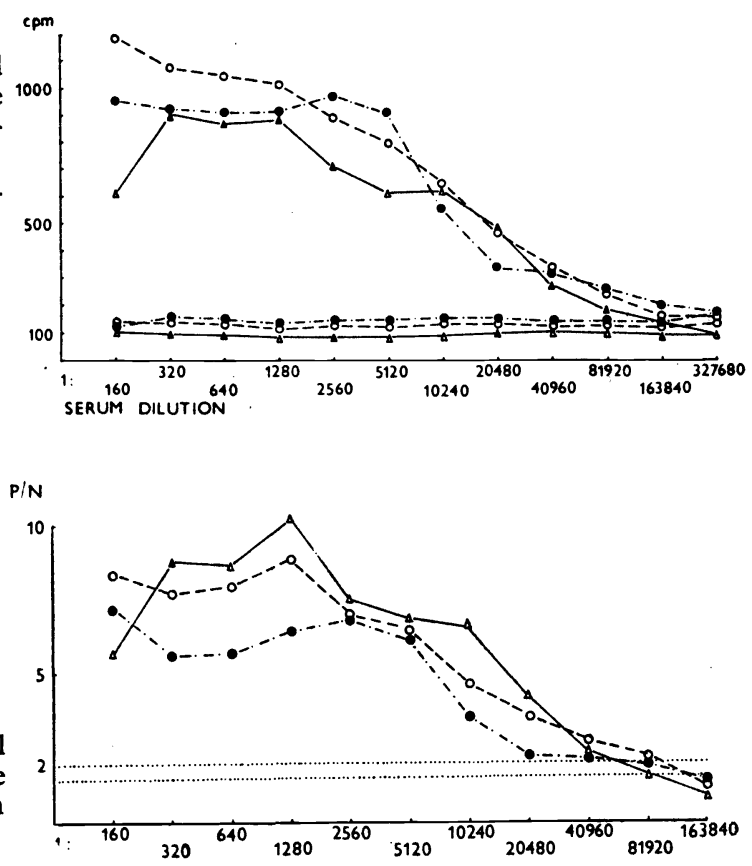

SERUM DILUTION

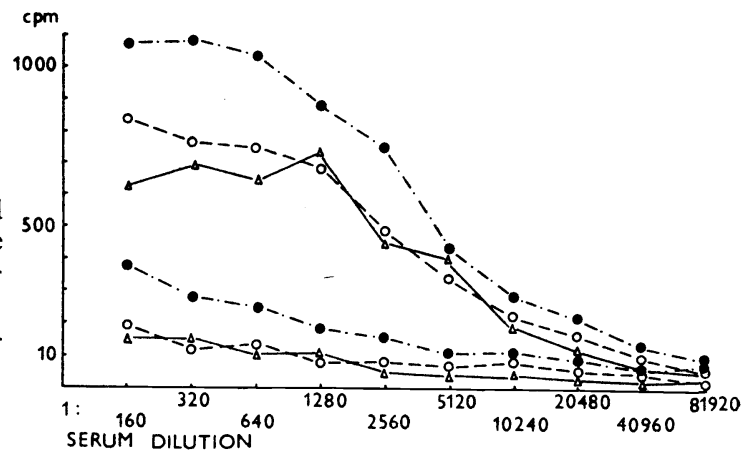

tination test demonstrated the presence of antibodies in the hyperimmune serum at the dilution of $1: 1024$.

A similar pattern of radioactivity in the individual dilutions of the hyperimmune and negative serum was obtained with antigens prepared from $M$. hyopneumoniae. The results are presented in Fig. 3. Almost the same level of radioactivity of the two sera was obtained at the dilution of $1: 81920$. The ratio of radioactivity in the individual pairs of the hyperimmune and negative serum is shown in Fig. 4. At the dilution of 1:20 480 antibody was demonstrated with all the three types of antigen; at the dilution of 1:40960 it was demonstrated with the corpuscular and sonicated antigen. In the next two dilutions dubious findings and only with the sonicated antigen were obtained. The indirect haemagglutination test demonstrated the presence of serum antibody at the dilution of $1: 1024$. 

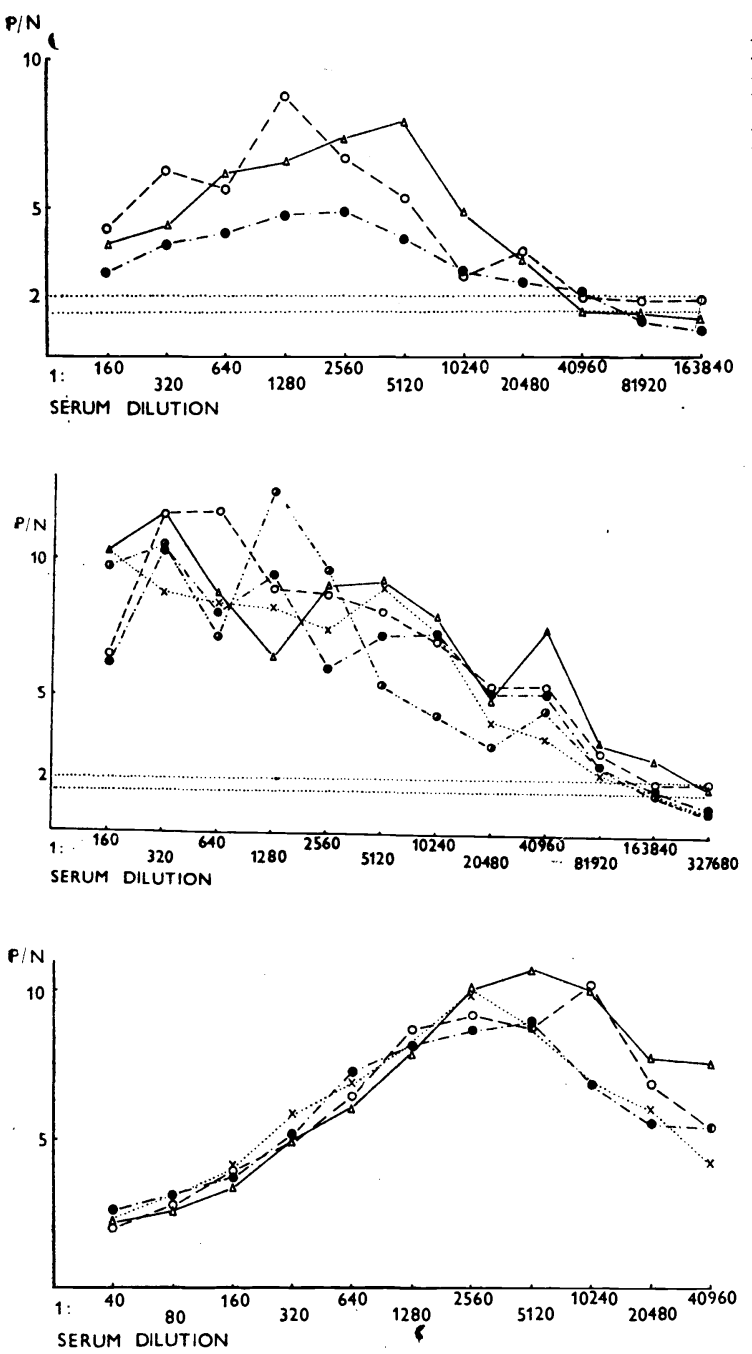

Fig. 4

Ratio of radioactivity in the individual pairs of hyperimmune and negative serum as a function of the dilution $\mathbf{P} / \mathbf{N}==$ positive/negative serum Same M. hyopneumoniae antigens as in Fig. 3.
Fig. 5

Ratio of radioactivity in the individual pairs of hyperimmune and negative serum as function of the dilution of sonicated M.hyorhinis antigen

Antigen dilutions:

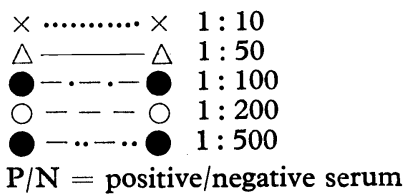

Fig. 6

Ratio of radioactivity of hyperimmune and negative serum as a function of the radioactivity level of ${ }^{125}$ I-labelled antibody

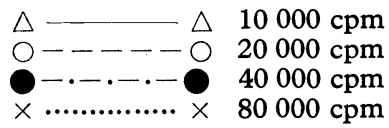

To find which dilution of sonicated antigen was best suited for coating the inner surface of microtubes, standardized $M$. hyorhinis antigen was diluted $1: 10$, $1: 50,1: 100,1: 200$ and $1: 500$ and tested with the hyperimmune and notoriously negative serum. Fig. 5 shows the ratio of radioactivity in the individual pairs of the hyperimmune and negative serum at these dilutions. The optimum dilution of the antigen was $1: 50$. Titres obtained with the remaining dilutions were approximately equal.

The antigens were incubated invariably for 16 hours at room temperature. To find how long the sera should be incubated to achieve optimum binding of the serum antibodies, incubation periods of 3, 8 and 16 hours were tested. No significant differences in the results were obtained when the incubation period was prolonged beyond 3 hours. 
Similarly, the results were not affected by varying the incubation period of ${ }^{125}$ I-labelled anti-swine IgG antibody within the range of 3 to 8 hours.

To determine, which radioactivity level of ${ }^{125}$ I-labelled anti-swine IgG antibody would be most convenient to use, the radioactivity range of 10000 to $80000 \mathrm{cpm}$ was tested. As can be seen from Fig. 6, the radioactivity level within this range had no significant effect on antibody titres demonstrated in the hyperimmune sera.

\section{Discussion}

Of the three different types of mycoplasma antigen tested in this study, those prepared by ultrasonic disaggregation proved the most suitable for practical application in view of the results and the relative ease of their preparation and standardization of their properties.

In contrast to Rodák et al. (1978) who evaluated a binding ratio as positive if it was 1.5 or higher, we did so only if it was at least 2.0 in view of high titres of the hyperimmune sera. In spite of this critical evaluation serum antibodies to $M$. hyorhinis and $M$. hyopneumoniae were demonstrated up to the dilution of $1: 40960$ and $1: 81920$, respectively, whereas indirect haemagglutination demonstrated the presence of serum antibodies only up to the dilution of $1: 1024$. Although the antigens were tested with hyperimmune sera, the results are encouraging.

\section{Př́prava a testování antigenů pro RIA stanovení protilátek při myko- plasmových infekcích prasat}

$\mathrm{K}$ průkazu protilátek $\mathrm{v}$ sérech prasat, infikovaných Mycoplasma hyopneumoniae a $M$. hyorhinis, pomocí RIA metody na pevném nosiči byly zkoušeny tři různě připravené antigeny, a to korpuskulární, desagregovaný dodecylsulfátem sodným a desagregovaný ultrazvukem. $Z$ praktického hlediska se jevil jako nejlepší antigen $z$ mykoplasmat desagregovaných ultrazvukem ředěný $1: 50 \mathrm{a}$ inkubovaný $\mathrm{v}$ polystyrenových mikrozkumavkách po dobu 16 hodin. Inkubace testovaného séra a ${ }^{125} \mathrm{~J}$ značené protilátky trvala 3 hod., prodloužení této doby nemělo vliv na získané výsledky. Radioaktivita aplikované značené protilátky v rozmezí $10000-80000 \mathrm{imp} / \mathrm{min}$ neměla signifikantní vliv na výśi dosaženého titru protilátek.

Подготовка и испытание антигенов для РИА определения аптивеществ при микоплазмениых инфекциях поросят

Для идентификации антивеществ в сыворотках поросят, инфицированных Mycoplasma hyopneumoniae и $M$. hyorhinis, с помощью метода РИА на прочном носителе проводились испытания трех подготовленных по-разному антигенов, а именно корпускулярного, дезагрегированного додецилсульфатом натрия и дезагрегированного ультразвуком. С практической точки зрени лучшим казался антиген из микоплазмєI, дезагрегированной ультразвуком, разбавленный в соотношении 1:50 и инкубированный в микропробирках из полистирола в течение 16 часов. Инкубирование проверяемой сыворотки и ${ }^{125} \mathrm{~J}$ меченного антивещества длилось 3 часа, продление указан- 
ного срока не оказывало влияние на полученные результаты. Радиоактивность используемого меченного антивещества в пределах $10000-80000$ имп/ мин не оказывала явного влияния на уровень достигнутого титра антивепеств.

\section{References}

BRUGGMANN, S. - KELLER, H.: Quantitative detection of antibodies to Mycoplasma suipneumoniae in pigs' sera by an enzyme-linked immunosorbent assay. Vet. Rec., 101, 1977 : $109-111$.

GOIŠ, M. - ŠISÁK, F. - KUKSA, F. - SOVADINA, M.: Incidence and evaluation of the microbial flora in the lungs of pigs with enzootic pneumoniae. Zbl. VetMed. B, 22, 1975: 205 to 219.

HAMPL, J. - TOMÁNEK, J. - KUKSA, F.: Detection of antibodies to Mycoplasma hyopneumoniae in pig sera by solid-phase radioimmunoassay. Proceedings of IX. Annual Meeting of European Society of Nuclear Methods in Agriculture, Brno, 1978:78

LAM, K. M. - SWITZER, W. P.: Mycoplasmal pneumonia of swine: Development of an indirect haemagglutination test. Am. J. vet. Res., 32, 1971: 1731-1736.

McCONAHEY, P. J. - DIXON, F. J.: A method of trace iodination of proteins for immunologic studies. Int. Arch. Allergy, 29, 1966: 185-189.

RODÁK, L. - ŠMÎ́, B. - HOLUB, A. - MENŠ́́K, J. - SEDLÁČEK, M. - ŠTĚPÁNEK, J.: Autoradiografický průkaz protilátek $\mathrm{v}$ tělních tekutinách. Project report, Brno, Veterinary Research Institute, 1978, p. 50.

TAYLOR, G.: Solid-phase micro-radioimmunoassay to measure immunoglobulin class-specific antibody to Mycoplasma pulmonis. Infect. Immun., 24, 1979: $701-706$. 